\title{
LOS PLANOS INÉDITOS DEL PROYECTO IMPULSADO POR EL OBISPO GÓMEZ DE TERÁN PARA LA AMPLIACIÓN DE LA CATEDRAL DE ORIHUELA
}

La catedral de Orihuela, debido a su condición original de iglesia parroquial, es una de las de menor tamaño de toda la geografía nacional. Esta circunstancia ha motivado que, desde que se elevó al rango de colegiata en 1413, aunque especialmente a partir de su consagración como catedral en el siglo XVI, se hayan sucedido diversas tentativas para conseguir la ampliación o reforma del edificio, llegándose incluso a plantear su traslado. Pero su ubicación en el centro de la urbe, constreñida entre el río, la montaña y estrechas calles que en su día fueron los principales ejes viarios de la población, ha llegado a dificultar enormemente cualquier posibilidad de extensión.

El actual templo catedralicio oriolano contó desde un principio con tres naves y girola, una estructura propia de las catedrales y colegiales, en lo que fue una iglesia parroquial. A principios del siglo XVI, su interior fue dotado de una mayor monumentalidad con la creación de un singular crucero, ideado por Pere Compte a partir de la supresión de dos pilares ${ }^{1}$. En cambio, estos destacados elementos no han logrado eclipsar las reducidas dimensiones que presenta esta iglesia, ya que éstas han constituido un motivo tradicional de descontento entre algunos prelados de esta diócesis, miembros del Cabildo catedralicio y de la población en general, fundamentalmente en lo que respecta a la angostura de su capilla mayor. Se tiene constancia de que la falta de espacio en el presbiterio ha llegado a dificultar el conveniente desarrollo o, al menos a mermar el esplendor, de algunos de los actos ceremoniales más destacados de la sede. Pero el problema se acentuaba aún más por el hecho de que, en el interior de su estrecha capilla mayor, también tenían derecho de asiento los representantes de la corporación capitular municipal².

Ante esta situación y entre los diversos intentos conocidos de renovación de la catedral oriolana, destaca la interesante propuesta que fue impulsada por el obispo Juan Elías Gómez de Terán a mediados del siglo XVIII ${ }^{3}$. De ella únicamente se tenían algunas vagas e imprecisas noticias ${ }^{4}$, hasta que fue estudiada por Juan Antonio Ramírez a finales de la década de los setenta

\footnotetext{
* Este trabajo ha sido elaborado en el marco del Proyecto de Investigación I+D HUM2006-12319, dirigido por el Dr. D. Germán Ramallo Asensio.

${ }^{1}$ Véase al respecto Berchez, Joaquín y Jarque, Francesc, Arquitectura Renacentista Valenciana (1500-1570), Valencia, 1994, p. 28.

${ }^{2}$ La negativa del Cabildo civil a renunciar a su derecho de asiento dentro de la capilla mayor, llegó a provocar duros enfrentamientos con el Cabildo catedralicio en los años 1726 y 1751, en este último caso se inició un largo pleito que no concluyó hasta 1758. Véase sobre ello Nieto FernándeZ, Agustín, Orihuela en sus documentos I. La Catedral. Parroquias de Santa Justa y Rufina y Santiago, Murcia, 1982, pp. 144-145; AA.VV., La luz de las Imágenes. Orihuela, Valencia, 2003, pp. 598-605.

${ }^{3}$ El primero de ellos tuvo lugar hacia el año 1569 y por lo tanto muy poco tiempo después de la creación del nuevo obispado de Orihuela, pero son muy pocos los datos que se tienen sobre él. SÁnchEZ PORTAS, Javier, "Intentos de ampliación y renovación de la catedral de Orihuela”, en AA.VV., La luz de las imágenes..., op. cit., p. 601. A mediados del siglo XVII se produjo otro intento de ampliación, muy poco conocido hasta el momento, por iniciativa del obispo don Luis Crespi de Borja, del que sabemos que no llegó a buen término a pesar de que contó con el producto del estanco del tabaco y jabón para poder costearlo. El siglo XVIII, fue el más prolífico en la preparación de proyectos para este fin.

${ }^{4}$ Durante mucho tiempo se consideró que este obispo "pretendió invertir sus caudales en la construcción de una nueva y suntuosa catedral, para lo cual se formaron los correspondientes planos que como recuerdo se conservan en la sacristía mayor actual". Así quedó recogido en las "Biografías de los Reverendísimos e Ilmos. Sres. Obispos que han gobernado y regido la Diócesis de Orihuela, desde que en ella fue erigida la Silla Episcopal desmembrada de la de Cartagena; con su resumen histórico de la Iglesia Catedral de esta ciudad”. Folletín de La Crónica, Orihuela, 1886. Ed. facsímil, Librería París-Valencia, Valencia, 1996.

Conforme a lo señalado, los planos referidos, que están custodiados en la actualidad en el Archivo de la Catedral de Orihuela pero que estuvieron expuestos anteriormente en la sacristía, son los que se han atribuido tradicionalmente al proyecto de Gómez de Terán (basándose para ello en una inscripción decimonónica que fue incorporada en la zona
} 
del pasado siglo ${ }^{5}$. A partir de entonces, se pudo conocer el auténtico carácter de este proyecto que preveía la extensión de la iglesia mayor de Orihuela, mediante la adición de una nueva capilla mayor. Ésta se adosaría al costado septentrional del viejo templo, cambiando con ello el sentido tradicional de su orientación oeste a este, por la de sur a norte. Conforme a esa variación, la entrada meridional, conocida como puerta de Loreto, pasaría a convertirse en la principal, al quedar situada a los pies de la nueva nave central. De ese modo, los primeros tramos de dicha nave quedarían constituidos por el crucero de la iglesia actual y, en su dilatado espacio, se levantaría un coro más amplio, así como la nueva capilla mayor, que resultaría mucho más desahogada que la existente.

Basándose en los datos aportados por las fuentes documentales, Ramírez logró interpretar gráficamente los principales rasgos e implicaciones urbanísticas que caracterizaban a este proyecto, dado que los diseños contemporáneos se daban por perdidos ${ }^{6}$. Afortunadamente, durante el transcurso de una investigación llevada a cabo en el Archivo Histórico Nacional, se ha hallado un interesante expediente que fue enviado al Consejo Real, en el que se incluyen los planos que ilustran el mencionado planteamiento arquitectónico.

El hallazgo de las trazas correspondientes al plan de extensión de la catedral que defendió Gómez de Terán, resulta de gran interés por contribuir al conocimiento de esta singular propuesta que nunca se llegó a materializar. Estos documentos constituyen la verdadera muestra gráfica de los caracteres estilísticos y formales que presentaba este programa, ilustrando las aspiraciones de un prelado que actuó como un gran benefactor de la diócesis oriolana durante los años 17381758, en los que se mantuvo al frente de la misma. Allí llevó a cabo numerosas empresas y fundaciones como la del cuartel, el Seminario Conciliar, las casas de Misericordia de Orihuela y Alicante, o las múltiples reparaciones efectuadas en diversas parroquias y conventos diocesanos. Pero sus afanes de mejora y engrandecimiento se centraron de un modo particular en la iglesia mayor, en la que se registró una gran actividad constructiva durante su episcopado, sucediéndose intervenciones de gran peso, como la renovación de la sacristía mayor, la edificación de la nueva sala capitular con su antesala, el archivo, la contaduría y la capilla de la Comunión. Contribuyó además a favorecer la solemnidad del culto en el principal templo de la diócesis, mediante numerosos encargos de orfebrería y con el establecimiento de un nuevo Ceremonial de Obispos. Su presencia en el interior de la catedral fue también realzada al sustituir la anterior silla portátil que servía de asiento para los prelados en el presbiterio, por un fastuoso trono episcopal elevado sobre gradas y cubierto con dosel ${ }^{7}$.

Pero a pesar de la relevancia de las actuaciones emprendidas en la iglesia mayor oriolana durante los primeros años del gobierno de Gómez de Terán, el principal problema de esta sede quedaba aún por solventar: su acusada falta de espacio. Por este motivo, el obispo se propuso firmemente emprender un plan de ensanchamiento de este templo, para lo que llegó a resultar decisiva la ceremonia de las honras fúnebres al rey Felipe V, celebrada en octubre de 1746. Según se refleja en el nuevo hallazgo documental, el desarrollo de este acto puso nuevamente en

\footnotetext{
inferior) cuando en realidad corresponden a un proyecto para la construcción de una nueva catedral, no a una ampliación de la existente, que fue lo que propuso realizar dicho obispo.

5 Ramírez Domínguez, Juan Antonio, El perfil de una utopía: La catedral nueva de Orihuela, Madrid, 1978. Este autor, tras realizar un profundo estudio documental y a la vista de los rasgos estilísticos que presentaban los planos mencionados anteriormente, lo que unido además a la presencia en ellos del escudo del rey Carlos III, llegó a determinar que estos documentos gráficos no debían corresponder al proyecto del obispo Gómez de Terán, sino a otro posterior.

${ }^{6}$ Ramírez Domínguez, Juan Antonio, El perfil de una utopía..., op. cit., p. 23 y figura 5.

7 Ramírez Domínguez, Juan Antonio, El perfil de una utopía..., op. cit., pp. 26-33; Nieto Fernández, Agustín, Orihuela en sus documentos..., op. cit., vol. 1, pp. 12 y 13; SÁnCHEZ PORTAS, Javier, "Intentos de ampliación y renovación de la catedral de Orihuela”, AA.VV., La luz de las imágenes. Orihuela, Valencia, 2003, pp. 600-605.
} 
evidencia las grandes carencias que presentaba el viejo edificio y, por ello, se decidió a comenzar la búsqueda de apoyos con los que secundar la iniciativa. Fue entonces cuando José Maseras de López, regidor perpetuo de la ciudad y comisario de la Junta de Parroquia, expuso la idea del obispo ante los componentes de la mencionada junta: “(...) por lo que se ha visto en el día de ayer, en que se celebraron las honras del difunto Rey y Señor D. Felipe Quinto de gloriosa memoria, y en que a la pena de la memoria de su pérdida, acompañó en esta ciudad y vecinos de ella, la fatiga de no poder satisfacer las ansias de su lealtad en su debida concurrencia, pues ocupado todo el principal cuerpo de la nave, con el túmulo y real panteón, no quedaban sino unos muy cortos tránsitos, que apenas bastaban para entrar y salir, experimentándose aun más la angustia y estrechez de sitio en la capilla mayor, donde celebró pontificalmente nuestro Iltmo. Prelado. Pues por la concurrencia del Ayuntamiento de la Ciudad, en ella no podían sostenerse en pie aún aquellos precisos ministros para la asistencia al altar y prelado, faltando en estos la separación precisa y distinción de clases, llegando a causar confusión y aún irreverencia en estos tan sagrados actos. Y contando que de mucho tiempo a esta parte, impelidas de los expresados motivos, muchas personas celosas del divino culto y de que la casa de Dios tenga la debida extensión; y de ver, que la que ha tenido el vecindario de esta Ciudad hace mayor la necesidad de la de su templo principal, han pensado y discurrido varios medios a este fin, teniendo siempre por acertado y único el que se haga una capilla mayor a la parte del norte de esta iglesia, uniéndole a la nave actual de ella, con lo que queda útil al todo de su cuerpo y todos los demás de su servicio, sin que se necesite variar ni utilizar el más mínimo, consiguiéndose al mismo tiempo una maravillosa extensión y ensanche, con que se logran todos los referidos fines (...)"8.

La Junta de Parroquia se manifestó a favor de esta propuesta que iba a ser encabezada por Gómez de Terán, por lo que mandó formar una comisión para que se encargase de todo lo concerniente a su posible ejecución, incluyendo la elaboración de los diseños pertinentes. Con este motivo se realizarían los cuatro planos que se han localizado, los cuales se presentaron respectivamente a los cabildos eclesiástico y civil con el fin de lograr su aprobación, pero ante sus negativas, el obispo decidió desplazarse hasta la Corte y los mostró personalmente ante el Consejo Real, esperando que el monarca se manifestase al respecto.

El primero de estos documentos gráficos (fig. 1) está firmado por Antonio Villanueva ${ }^{9}$ y es el único en el que se ha indicado la fecha de su realización: el año 1748. Corresponde a un "Plano geográfico en que se demuestra la porción del casco de la ciudad de Orihuela, el río que lo divide y un trozo del arrabal de S. Agustín"10. En él se ha representado el núcleo urbano de la localidad alicantina, con particular atención al enclave que ofrece su catedral, justo en la zona donde más se estrecha la distancia entre el río Segura y el monte de San Miguel.

La planta del edificio eclesiástico se muestra con todo detalle y junto a ella se ha resaltado en color rojo el lugar previsto para llevar a cabo la ampliación. Por medio de una leyenda, se ha incluido la relación pormenorizada de las casas que era necesario comprar para realizar este plan, con indicación de sus respectivos propietarios. Además de ello, se puede apreciar el nuevo trazado que presentaría la calle de la Feria, que es la que discurre por el lado septentrional de la iglesia, cuyo tránsito no se iba a ver interrumpido, sino que quedaría circundando a la zona prolongada.

${ }^{8}$ España, Ministerio de Cultura. Archivo Histórico Nacional (en adelante AHN). CONSEJOS, Patronato, leg. 48377, fol. 38 .

9 Antonio de Villanueva nació en Lorca (Murcia) en el año 1714. En Orihuela transcurrió varios años y allí realizó sus estudios de Artes y Letras. Se conoce que cultivó la Arquitectura y que gozó de una cierta relevancia como pintor antes de profesar como religioso franciscano. Así lo recoge Baquero Almansa, Andrés, Catálogo de los Profesores de las Bellas Artes Murcianos, Murcia, 1913, pp. 259-261.

10 AHN. CONSEJOS, Consejos, M.P.D. 2580. 
El segundo plano ${ }^{11}$ (fig. 2) presenta una planta de la catedral oriolana en la que se ha incorporado ya el amplio anexo de la capilla mayor y girola en su costado norte, diferenciándolo de la parte antigua con la utilización de un tono distinto. De este modo, se puede apreciar que la extensión de superficie que se propuso construir venía a suponer un incremento muy notable respecto a la ya edificada, pues prácticamente la llegaba a superar en dimensiones. Según este plan, el futuro coro, mucho más espacioso que el existente, quedaría situado ocupando gran parte del actual crucero, de tal modo que se iba a mostrar ligeramente descentrado respecto a la que pasaría a convertirse en la portada de los pies y, por lo tanto, en la principal. Dos accesos laterales se abrirían en los extremos del nuevo crucero, el cual se iba a disponer en el tramo inmediato al muro septentrional del viejo templo, cuya superficie debía ser horadada con el fin de comunicar ambas partes y formar un todo único.

La nueva capilla mayor que se planteaba edificar, venía a reproducir a mayor escala el mismo modelo poligonal que la anterior, solucionando así los problemas originados en aquélla por la escasez de espacio disponible. En su interior se podrían disponer con bastante holgura todos los elementos necesarios para el culto, junto con el trono episcopal y los asientos del Cabildo eclesiástico. Asimismo, en la zona inmediata al presbi-

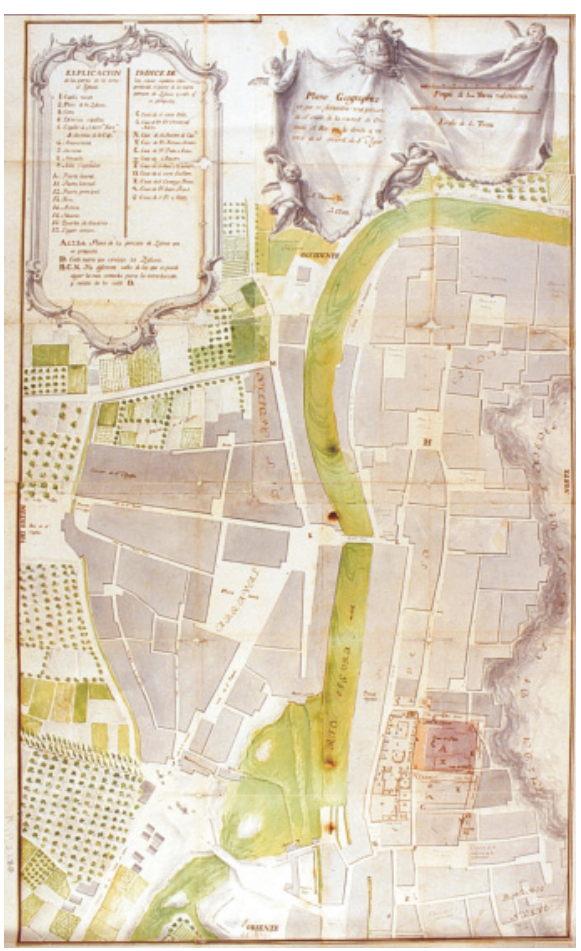

Fig. 1. Plano de la ciudad de Orihuela con indicación de su catedral.

A. Villanueva. 1748. terio se colocarían los dos bancos del Ayuntamiento, tal y como prescribía la costumbre local.

Este diseño parece corresponder a una primera propuesta gráfica del proyecto de extensión del templo, pues ofrece dos posibles soluciones de remate para la nueva cabecera: un testero plano con deambulatorio, o una forma absidal más dilatada y con doble girola tras la capilla mayor. En la leyenda que lo acompaña se recoge información al respecto: "Todo lo que está de color es la obra nueva que se añade a la antigua aprovechándose de todo sin derribar cosa alguna: con lo que la iglesia que era de tres naves, se hace de cinco; haciendo puerta de los pies la que hoy es del costado y está cortado este medio arco, por si no se quiere alargar más que a donde está este cuadro."

Existe también una segunda planta del edifico ${ }^{12}$ (fig. 3) que presenta un carácter mucho más elaborado y definitivo que el que se ha visto anteriormente. Está firmada en su parte inferior por un arquitecto de origen murciano, Marcos Evangelio. Este maestro, nacido en Cartagena, desarrolló su actividad en el segundo tercio del siglo XVIII. En su ciudad natal, participó en las empresas más destacadas del momento, como el trazado y construcción de la antigua iglesia de la Caridad o la supervisión de las obras del Arsenal. También trabajó en la zona alicantina, donde dirigió la construcción de la iglesia de la Asunción de Elche, desde 1758 hasta su muerte en

\footnotetext{
11 AHN. CONSEJOS, M.P.D. 2581.

12 AHN. CONSEJOS, M.P.D. 2582.
} 


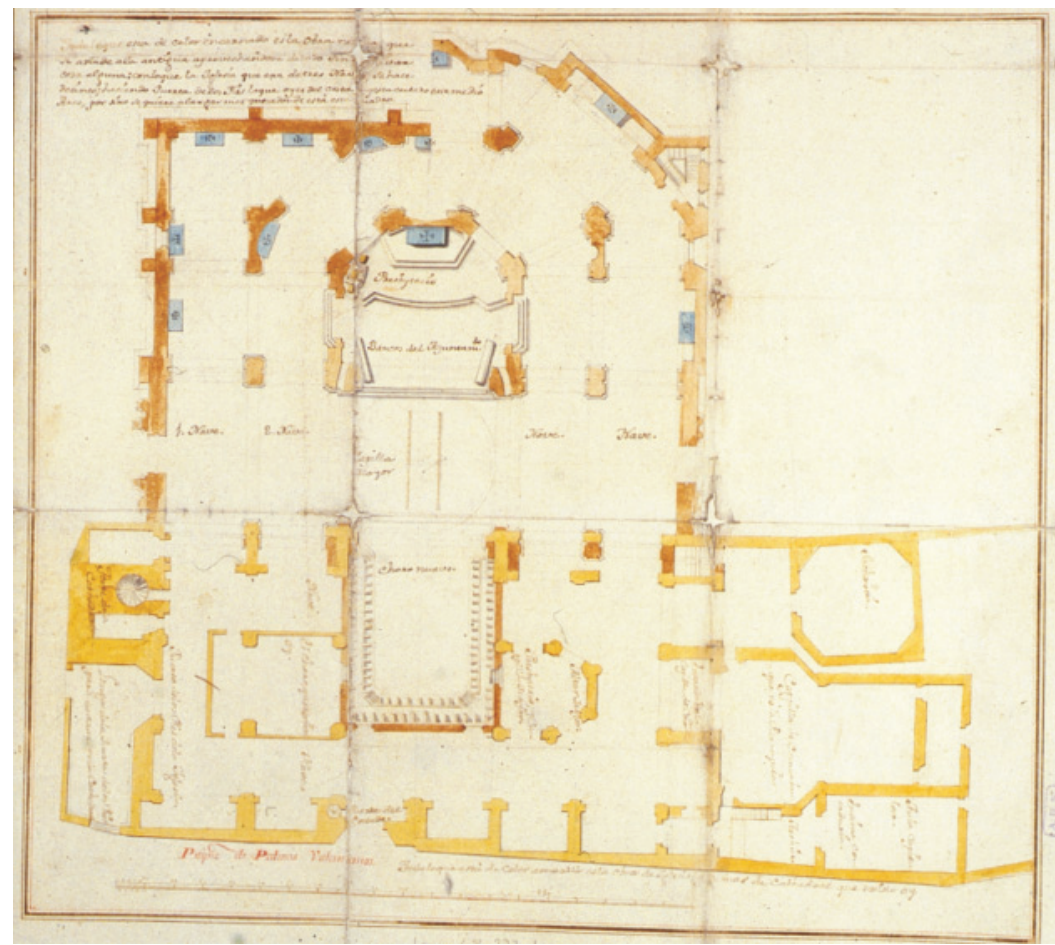

Fig. 2. Diseño elaborado para la ampliación de la catedral de Orihuela, ca. 1748.

1767. Además de ello, fue profesor de Arquitectura y la Real Academia de Bellas Artes de San Fernando le nombró académico de mérito en junio de $1763^{13}$.

El carácter más acabado que ofrece este segundo diseño, vendría a confirmar la hipótesis de que el anterior pueda corresponder a un primer apunte o propuesta gráfica sobre el plan de extensión de la catedral, el cual pudo ser realizado probablemente por el mismo arquitecto, pero con un carácter más provisional, lo que justifica el hecho de que no se encuentre firmado. De ese modo, esta otra planta ofrecería ya la disposición final elegida para encauzar la intervención arquitectónica. Así, tal y como Gómez de Terán había propuesto, se iba a cambiar la orientación del templo, con lo que el principal acceso se ubicaría en la antigua portada lateral de su costado meridional y, por lo tanto, frente al palacio episcopal, que además había sido remodelado recientemente ${ }^{14}$. Este hecho es digno de subrayar, ya que, aunque la distancia no iba a suponer una variación importante sobre la situación anterior, el nuevo ingreso sí que lograría ofrecer un marco mucho más monumental y despejado para la entrada del obispo al interior catedral. De esta forma, el prelado accedería directamente al amplio y diáfano espacio de la nueva nave central,

13 Baquero Almansa, Andrés, Catálogo de los Profesores..., op. cit., pp. 252-253.

${ }^{14}$ Hacia el año 1733, el obispo Flores Osorio mandó realizar una profunda renovación en el Palacio Episcopal que logró dotarlo de una mayor monumentalidad y barroquismo. Sin embargo, Ascensio de Morales, entre los datos aportados de su exploración a los archivos de Orihuela y Alicante en el año 1752, recoge que Juan Elías Gómez de Terán llevó a cabo una remodelación de este edificio durante su mandato. AHN, ESTADO, leg. 2945, Exp. 4, fol. 34. De este modo, el contraste creado entre ambas construcciones haría aún más recomendable, a los ojos de este último prelado, la mejora del templo catedralicio. 


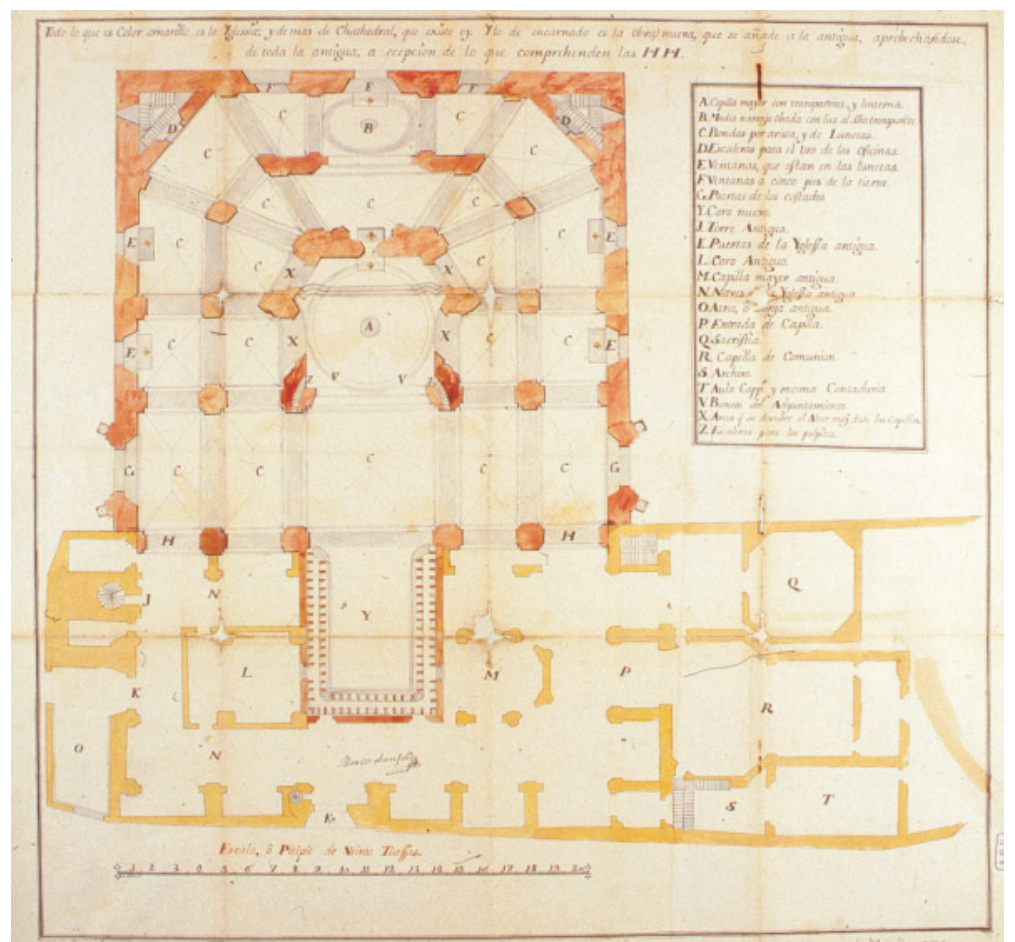

Fig. 3. Planta que ilustra el proyecto de extensión de la catedral. Marcos Evangelio, ca. 1748.

claramente contrapuesto al estrecho pasillo existente hasta entonces, el cual le resultaría bastante angosto por la inmediata presencia del coro. Esta circunstancia constituye una clara muestra más de la importancia que este obispo otorgaba al sentido escenográfico, algo que unido a su conocido afán de monumentalidad, resultan ser dos rasgos muy característicos de una mentalidad propiamente barroca, como parece ser que lo fue la suya.

La opción de remate de la cabecera por la que se optó finalmente, fue una solución intermedia que aunaba la doble girola en torno a la capilla mayor y un testero plano hacia la parte exterior. Esto se consiguió al incluir escaleras en los ángulos, por las que se pensaba dar acceso a las nuevas oficinas, que se dispondrían en la zona superior. Dichas oficinas vendrían a complementar a las ya existentes en el sector oriental del viejo edificio y, al habilitarlas sobre las naves laterales del templo, se evitaba tener que disponer de solares adicionales para este fin. Esta preocupación por proporcionar estancias funcionales para la sede ampliada, resulta ya de por sí bastante interesante. Pero se hace aún más, si se considera el hecho de que, como bien se sabe, la gran dificultad que se presentaba para la puesta en práctica de este proyecto arquitectónico, era la de la ausencia de espacio disponible, ya que se hacía necesaria la ocupación de una calle pública y la compra de diversas viviendas de particulares.

Otro interesante aspecto formal que se refleja en este diseño, firmado por Marcos Evangelio, es el de la incorporación de una amplia linterna sobre la capilla mayor, la que, además, iba a contar con un transparente en su parte posterior (identificado con la letra A). Frente al transparente, se tenía previsto disponer un ámbito cubierto mediante una bóveda ovalada "y con luz a dicho transparente" (letra B), binomio éste que, por lo tanto, presenta ecos de gran barroquismo. Respecto a la planta que se ha visto anteriormente, ésta incluye otra serie de novedades, como es la superficie totalmente lisa y uniforme que ofrece la cara exterior del muro, o una distinta 
colocación de los pilares en la zona de la capilla mayor y girola, algunos de los cuales muestran una llamativa disposición sesgada.

El último diseño que incorpora el expediente mencionado ${ }^{15}$ (fig. 4) fue realizado también por Marcos Evangelio y representa el alzado de la parte correspondiente a la ampliación, vista desde el futuro crucero. Destaca aquí, por su volumen, la cúpula que se alzaría sobre la nueva capilla mayor, horadada en su tambor y linterna. Su cubierta exterior manifiesta una característica forma contracurva que viene a vincularla con la tradición del barroco andaluz y levantino ${ }^{16}$. Sin embargo, la elección de la pizarra para su revestimiento no resulta tan habitual en esta zona, donde se ha recurrido tradicionalmente al empleo de materiales cerámicos que, en algunas ocasiones, logran ricos efectos decorativos con el empleo de vistosas policromías.

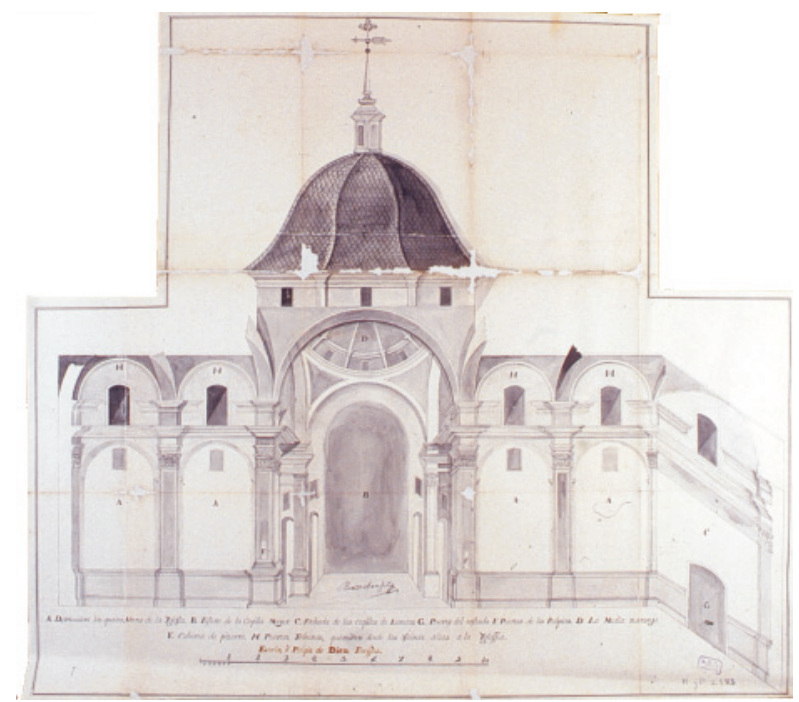

Fig. 4. Alzado del nuevo crucero y capilla mayor que se propuso realizar en la catedral de Orihuela. Marcos Evangelio, ca. 1748.

El arquitecto representó también un fragmento del aspecto interior que ofrecería la media naranja situada sobre la capilla mayor (letra D). En ella aparece sombreado su testero, de tal modo que no se aporta ningún detalle del transparente que se iba a realizar en su parte posterior, tal y como se había indicado en la planta correspondiente. Lamentablemente, por este motivo, no es posible conocer la disposición ideada para este destacado elemento, el cual hubiera podido llegar a representar un paso intermedio entre la exhuberancia barroca del transparente de la catedral toledana y la versión neoclásica del trazado por Ventura Rodríguez para la iglesia mayor de Cuenca ${ }^{17}$.

15 AHN. CONSEJOS, M.P.D. 2583

16 Galera ANDReu, Pedro, "La cúpula de perfil contracurvo en el Barroco murciano y andaluz", Imafronte, n. os $^{8-9}$, 1992-1993, pp. 167-187.

17 Prados García, José María, "Las trazas del Transparente y otros dibujos de Narciso Tomé para la Catedral de Toledo", Archivo Español de Arte, 49, 1976, pp. 387-416; BARrio Moya, José Luis, "Ventura Rodríguez y sus obras en Cuenca", Estudios sobre Ventura Rodríguez (1717-1785), Madrid, 1985, pp. 259-269; AzcÁRATe LuxÁn, Isabel, "Dibujos de Ventura Rodríguez para la catedral de Cuenca en la Colección Rabaglio", Academia, 88, 1999, pp. 57-64.

La capilla de san Julián o Transparente de la catedral de Cuenca, fue trazada por Ventura Rodríguez en 1752, por lo tanto, muy pocos años después de la elaboración de estos planos por Marcos Evangelio. 
Tampoco se muestran los pormenores de otro de los lugares más interesantes que conformaban esta propuesta arquitectónica, que no es otro que el que quedaría cubierto con una bóveda ovalada y situado frente al mencionado transparente. Resulta obvio que la cubierta de este último ámbito iba a presentar una altura mucho menor que la de la cúpula principal. A pesar de ello, estaba previsto que resaltase sobremanera en el nuevo templo catedralicio por la adopción del óvalo para su cubierta, forma que despertó gran interés entre los arquitectos del barroco, pero que también lo hizo entre los académicos, quienes experimentaron abundantemente con ella y con sus diversas variantes. De esto se deriva que, aunque no se haya precisado el destino final que iba a tener este lugar, éste iba a resultar, sin duda alguna, de gran importancia para la sede.

En lo que respecta a la disposición del alzado, sobresale el enorme contraste que se iba a acusar entre la obra del viejo templo y la nueva zona que se pretendía construir, de tal modo que la estructura gótica no encontraría ninguna solución de continuidad en el sector correspondiente a la ampliación. Para él, se optó por un lenguaje de tipo clasicista, con empleo de pilastras cajeadas de orden corintio y una doble cornisa de acusado saliente. El perfil apuntado de los arcos y crucerías de la parte existente, daría paso así a las rotundas formas de los arcos de medio punto y bóvedas de arista de la zona proyectada, que harían su aparición a partir del nuevo crucero. En el muro perimetral estaba previsto disponer ventanas coincidiendo con los lunetos de las bóvedas, mientras que hacia la zona interior se abrirían "puertas en las tribunas que miran desde las oficinas altas a la iglesia", tal y como se refleja en el plano con la letra $\mathrm{H}$.

En este diseño se advierte además una cierta contención ornamental ${ }^{18}$, que entronca ya con la arquitectura propiamente académica, con la que estaba familiarizado su tracista, pero que no excluye la presencia de elementos de claro signo barroco en el planteamiento general, los cuales pudieron ser incluidos, probablemente, por deseo expreso del obispo.

Con la realización de este proyecto, Gómez de Terán se propuso, según sus propias palabras, "conseguir que corresponda el nombre de iglesia catedral a la realidad de serlo"19. Esta afirmación no deja lugar a dudas acerca de lo inadecuado que le debía resultar el edificio para el rango eclesiástico que ostentaba. Por este motivo, el prelado se afanó en conseguir un planteamiento que se pudiese llevar a la práctica sin demasiadas objeciones, y en el que todo estuviese calculado hasta el más mínimo detalle. Para poder costear la obra, debía recurrir al polémico arbitrio llamado del Matadero, lo que justificó al señalar que con ello estaba cumpliendo con lo señalado en "la sesión 21, capítulo 7, del Concilio de Trento, en la que se mandó a los obispos a que como delegados de la Santa sede, apliquen las rentas eclesiásticas y en defecto de éstas, usen los remedios más oportunos para obligar a los parroquianos a que contribuyan, removiendo cualquier apelación, excepción y contradicción (...) no quedando otra obra publica, ni más necesaria, que la mencionada de capacitar la iglesia catedral" 20 .

La idea de aprovechar el antiguo templo y aumentarlo por su lado norte, la había puesto el mismo Dios en su mente ${ }^{21}$, por lo que el prelado sentía el deber de llevarla a la práctica. Ésa era la mejor posibilidad de extensión que existía, después de la construcción de nuevas estancias en el costado oriental y ante la presencia de la torre en el occidental. De hecho, cualquier ampliación por estos frentes hubiese resultado enormemente desproporcionada. Además, el cambio de orientación no supondría ningún obstáculo en sí mismo, dado que, por razones urbanísticas o

\footnotetext{
${ }^{18}$ En ese aspecto se puede señalar que viene a anticipar ya la desnudez de la catedral nueva de Lérida, que fue trazada en 1760. VILÁ I ToRNos, Frederic, La catedral de Lleida: segle XVIII, Lleida, 1991.

19 AHN. CONSEJOS, Patronato, leg. 48377, fol. 10.

${ }^{20}$ AHN. CONSEJOS, Patronato, leg. 48377, fol. 2.

${ }^{21}$ Archivo Municipal de Orihuela, Libro de Actas Capitulares del año 1749, fols. 261-265. Cit. en Ramírez DoMíNGUEZ, Juan Antonio, El perfil de una utopía..., op. cit., p. 68.
} 
por motivos de otra índole, eran ya muchos los templos que no seguían la tradicional orientación este-oeste.

Para elaborar el proyecto, se realizó un cálculo pormenorizado de todos los gastos que llevaría implícitos la nueva construcción y se tomaron medidas para abaratar costes. Por ejemplo, no se consideraba necesario que toda la obra fuese de piedra, sino que sólo lo sería la parte exterior, de tal modo que se emplearía la mampostería y el ladrillo para el resto "en cuya forma está todo lo actual de la iglesia"22. Con el fin de minimizar las posibles molestias ocasionadas por los trabajos de construcción, estaba previsto que su desarrollo no implicase el cese del culto divino, ya que éste continuaría en el antiguo templo mientras se edificaba la nueva cabecera. Una vez que esta parte estuviese concluida, se uniría a la iglesia medieval mediante el derribo de su muro septentrional ${ }^{23}$.

Finalmente, y a pesar del alto grado de preparación y madurez que llegó a alcanzar la propuesta episcopal, pesaron más los inconvenientes económicos y urbanísticos, que las ventajas que de su aplicación se derivaban. Faltó el apoyo de la población, que se negaba a asumir más gravámenes, y también el de un Cabildo catedralicio que se venía oponiendo a las iniciativas de este prelado, aún a pesar de que, como el mismo prelado había advertido, éstas fuesen en su beneficio $^{24}$.

En 1753, seis años después de su visita a la corte, el obispo Juan Elías Gómez de Terán se dirigió nuevamente al Consejo Real con el fin de obtener el beneplácito del monarca para la realización del proyecto. Para ello hizo hincapié en el hecho que la obra se podría llevar a cabo sin necesidad de aplicar el arbitrio del matadero que, por otra parte, tanta polémica había suscitado. Asimismo, reincidió en las ventajas urbanísticas de la iniciativa y en el hecho de que así se pondría solución al viejo problema del derecho de asiento de los representantes del poder civil en el interior de la capilla mayor. Éstas fueron algunas de sus palabras: “(...) A Dios gracias, con los sobrantes que han caído en estos últimos seis años y caigan en los otros seis siguientes, hay todo lo suficiente, sin necesitarse del arbitrio pedido del Matadero, ni de imposición alguna, a ninguno de los interesados, para empezar y echar cimientos y para comprar de dos a tres casas, de valor todas tres de dos a tres mil pesos; para no estorbar ni quitar ninguna de las dos calles, en cuyo medio está la catedral, sí de beneficiar a las demás: a la Calle Mayor, poniendo en ella la fachada principal de la misma catedral, que ahora está en una angosta callejuela, que sube a la otra de al lado de la catedral, que llaman de la Feria; por cuya calle no puede pasar un solo carruaje, sin exponerse a tropezar en la mitad de la torre, que coge la media calle: Y compradas dichas tres casas se ensancha más que al doble, y al mismo tiempo se abre paso a otra de las mejores calles, que no tiene salida, sólo a costa del corto rodeo que hace la pared foránea de dicho presbiterio, por lo que se entra en la misma calle, que queda de mayor espacio que antes. Y siendo V.M. Patrono de dicha iglesia, y no pudiendo por sí el obispo empezar sin su Real beneplácito, Suplica

${ }^{22}$ AHN. CONSEJOS, Patronato, leg. 48377, fols. 20 y 43. RAMíREZ calculó los costes que supondría la nueva obra, tomando como referencia los de la recién construida Capilla del la Comunión y llegando a la conclusión de que su realización no hubiese resultado utópica en absoluto. Así lo indica en la p. 44 de su ya mencionado libro.

23 AHN. CONSEJOS, Patronato, leg. 48377, fol. 1.

${ }^{24}$ En el expediente que fue enviado al Real Consejo, se encuentra también el informe redactado por la corporación capitular catedralicia, acerca de la no conveniencia de realizar este proyecto. En él se recogen afirmaciones del tipo "No podemos alcanzar por qué razones pueda esta obra colocarse en el predicamento de necesaria, porque si especulamos la contextura o articulación de la presente iglesia, la vemos tan firme, robusta y maciza como lo estaba cuatro o cinco siglos antes". O también "no podemos comprender como será factible la nueva obra y calle, porque, vistas las desigualdades y embarazos del terreno, nacen otros mayores inconvenientes, que procuraremos hacer presentes..." AHN. CONSEJOS, Patronato, leg. 48377, fols. 128-139.

Asimismo, otros aspectos negativos de la posible incidencia de la realización de este proyecto sobre el entramado urbano de Orihuela fueron recogidos por RAmírez DomíngueZ, Juan Antonio, El perfil de una utopía..., op. cit., pp. 44-48. 
el obispo se digne V.M. confirmar el acuerdo de la real Junta y que así de estos sobrantes como de los que pueda haber de las parroquias de la misma naturaleza, ayuden hasta la conclusión, sin otro impuesto, ni carga, ni repartimiento; pues de este modo se desvanece la controversia de Bancos del Ayuntamiento y se espera que en seis años se redima cuanto padece el Sagrado culto, hasta tocar en lo sustancial de su solemnidad; y los eclesiásticos y vasallos de V.M. crezcan y dilaten su fervor y devoción en medras espirituales..."25.

Aunque este planteamiento no pudo seguir adelante con éxito, la preocupación por el tema continuó vigente, tal y como lo demuestra la preparación de un proyecto para la construcción de una nueva catedral en Orihuela que se elaboró poco más de una década después, parece ser que durante el episcopado de Pedro Albornoz y Tapia ${ }^{26}$. Los planos "interior" y "exterior" que fueron realizados con este motivo, son los que, erróneamente, se han considerado durante tanto tiempo como correspondientes a la propuesta del obispo Gómez de Terán, conforme a lo que se hizo constar en una inscripción posterior, situada en la parte inferior de ambos ${ }^{27}$.

FRANCISCA DEL BAÑo MARTíneZ Universidad de Murcia

25 AHN. CONSEJOS, leg. 19331, exp. 11, s.f.

${ }^{26}$ El interés por la ampliación o renovación de la catedral oriolana no supone, en absoluto, un hecho aislado, ya que durante el periodo barroco numerosas catedrales españolas, fueron objeto de intervenciones de este tipo. Sobre este asunto véase RAMALlo AsEnSio, Germán, "Aspectos generales de las catedrales españolas en el Barroco y su proyección al siglo XIX”, Las catedrales españolas del Barroco a los Historicismos, Murcia, 2003, pp. 11-40. Mención aparte merece la gran atención que se otorgó también en aquella época a la dotación o remodelación de sus estancias auxiliares, tema que ha constituido el objeto de mi tesis doctoral: Estancias de uso y representación al servicio de las catedrales españolas durante el Barroco, Murcia, 2008.

27 Dichos planos se encuentran reproducidos en Ramírez Domínguez, Juan Antonio, El perfil de una utopía..., op. cit., figuras 6 y 7; AA.VV., La luz de las imágenes..., op. cit., pp. 601-602. 